\title{
An acute coronary syndrome in Antarctica
}

\author{
Mathieu Carron $^{1}$, Fanny Hamard ${ }^{1}$, Jacques Levraut ${ }^{1}$, Nicolas Blondeau ${ }^{2}$ \\ ${ }^{1}$ Emergency Department, Centre Hospitalier Universitaire de Nice, Nice, F-06001, France \\ 2Université Côte d'Azur, CNRS, UMR-7275, IPMC, Sophia Antipolis, F-06560, France
}

\begin{abstract}
Cruise tourism to Antarctica is constantly growing. Passengers and crewmembers may experience illnesses or injuries while traveling to remote areas with harsh weather conditions from where prompt evacuation is mostly unavailable. While a small explorer ship was at Wilhelmina bay ( $64^{\circ} 39^{\prime}$ South and $62^{\circ} 08^{\prime}$ ' West) in the Antarctic Peninsula, a 73-year-old male passenger presented with acute chest pain after two short excursions off the vessel in cold weather conditions. He was treated on board and remained clinically stable until the ship reached Ushuaia at the end of the cruise which was 5 days after the symptoms onset.
\end{abstract}

(Int Marit Health 2019; 70, 3: 167-170)

\section{Key words: acute coronary syndrome, chest pain, myocardial infarction, cruise ship, Antarctica}

\section{INTRODUCTION}

Antarctic cruise tourism has steadily increased - from 6,704 tourists in 1992 to 27,537 in 2004 and 45,083 in 2016-2017. The cruises typically last 10 to 15 days and most passengers are elderly and American [1]. The seas are often rough and the remote Antarctic Peninsula exhibits extreme weather conditions, all factors that prohibit medical evacuation [2]. Very cold and windy weather, which are weather conditions encountered in Antarctica, can contribute to acute coronary syndrome [3]. Myocardial infarction is a condition that physicians on board fear. This report concerns a 73-year-old cruise passenger who experienced acute chest pain while his ship was at Wilhelmina Bay, in the Antarctic Peninsula.

\section{MEDICAL CONDITIONS}

On November $23^{\text {rd }}, 2017$, at 8:00 hours, while the ship was cruising the Wilhelmina Bay $\left(64^{\circ} 39^{\prime}\right.$ South and $62^{\circ} 08^{\prime}$ West; close to the Antarctic Peninsula), a French 73-year-old male passenger consulted the ship physician because of chest pain. It had started the previous day after a windy and freezing cold zodiac cruise, then disappeared, but recurred in the afternoon during a short hike ashore in similar cold and windy conditions. The chest discomfort, described as "tightness" continued and increased during the night. An occasional smoker, the patient's only known medical condition was an elevated but untreated high cholesterol level. On presentation, the patient's vital signs were: heart rate 70 beats/min, oxygen saturation $98 \%$, respiratory rate 15 breaths/min, blood pressure 160/80 $\mathrm{mmHg}$, and body temperature $98^{\circ} \mathrm{F}$. His initial electrocardiogram revealed signs of anterior myocardial ischaemia and left ventricular hypertrophy (Fig. 1). His cardiac enzyme troponin level was increased to 104 ng/L (normal below 50 ng/L). By tele-consultation from the Medical Maritime Consultation Centre in Toulouse, France, a cardiologist confirmed the onboard

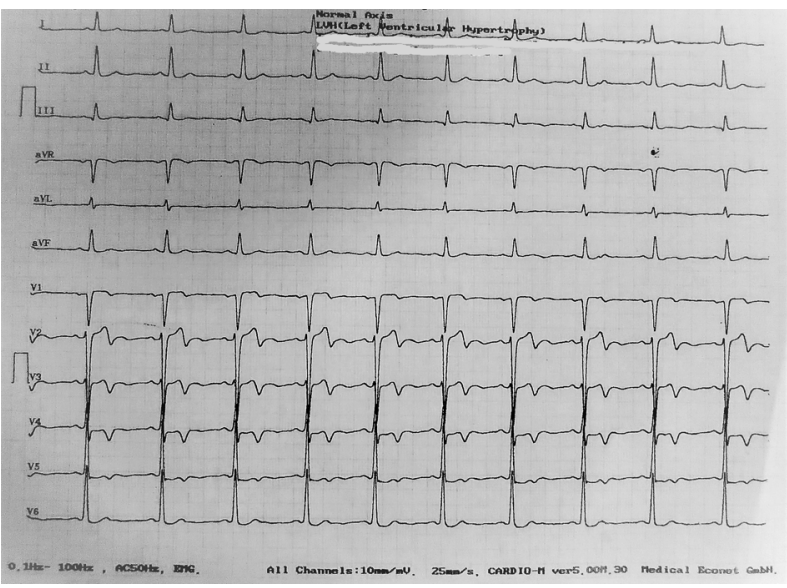

Figure 1. Wellens syndrome. Terminal inversion of T-wave from V1 to V3, showing an epicardial ischaemia. Left ventricular hypertrophy 


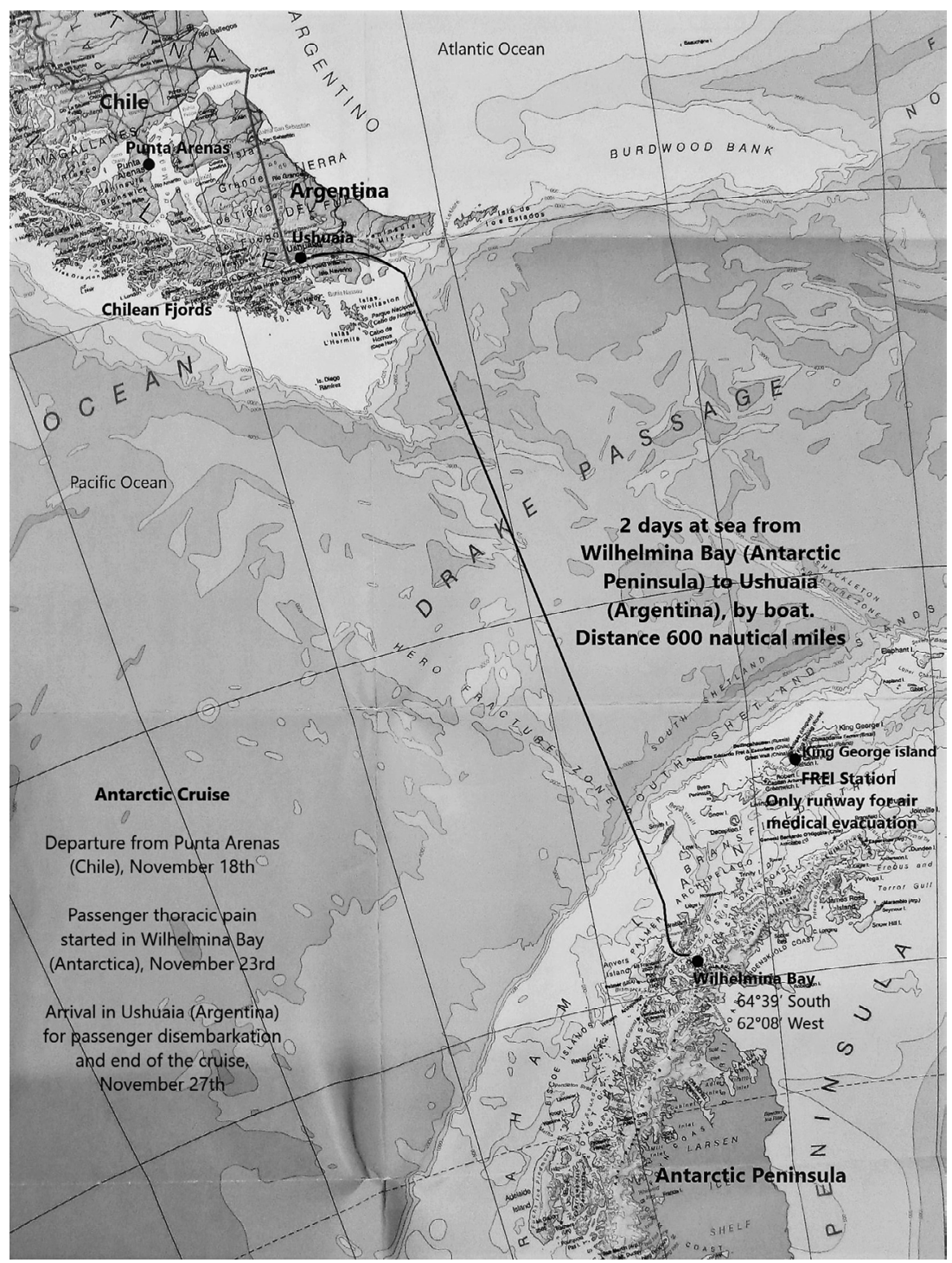

Figure 2. Navigation map between Wilhelmina Bay (Antarctica) and Ushuaia (Argentina) during an Antarctic cruise

diagnosis of acute coronary syndrome and agreed that thrombolysis was not indicated because no ST-segment elevation was seen. The patient was treated with aspirin, enoxaparin, ticagrelor and omeprazole. A trinitrine patch was prescribed to decrease a persistent chest pain. The next day, on November $24^{\text {th }}$, his troponin level increased to $255 \mathrm{ng} / \mathrm{L}$ while the electrocardiogram was unchanged. The patient remained stable under cardiac monitoring on board and was transferred urgently to a hospital upon arrival in Ushuaia on November $27^{\text {th }}$, which was the date initially scheduled for arrival at Ushuaia.

\section{FOLLOW UP AND OUTCOME}

At Ushuaia hospital admission, the electrocardiogram did not show any acute ischaemic signs while the troponin level increased to $710 \mathrm{ng} / \mathrm{L}$. His cardiac systolic function was preserved. On November $29^{\text {th }}, 7$ days after symptoms' onset, a coronary angioplasty was performed and one vascular stent was implanted. He had an uneventful recovery.

\section{SHIP, ROUTE AND WEATHER CONDITIONS}

The ship (length: 466 feet, beam: 59 feet, tonnage: 10700 and 6 decks), had a capacity of 200 passengers and 140 crewmembers. On board, the medical facilities were composed of two ward rooms and urgent care was available. One emergency care doctor was on board since 2 months, with one nurse to help him. He had a previous training in maritime medicine. Small laboratory facilities were available for cardiac enzymes, biochemical and haematological analysis.

The ship left Punta Arenas, Chile, on November $17^{\text {th }}$ and arrived at Ushuaia, Argentina, on November $27^{\text {th }}, 2017$ (Fig. 2). 
After the departure, the ship sailed south in bad weather. Temperatures were between $-4{ }^{\circ} \mathrm{C}$ and $4{ }^{\circ} \mathrm{C}$ during the whole cruise. On November $18^{\text {th }}$, passengers took part in a zodiac cruise in front of Garibaldi Glacier in the Chilean Fjords in cold, windy and humid weather. The next day, in Puerto Williams, they experienced heavy snow while they were walking in town. The ship spent 2 days in rough seas with 8-metre swells crossing the Drake Passage to reach the Antarctic Peninsula, where passengers were exposed to freezing wind and snow every day if participating in zodiac cruises or short hikes ashore. Because the weather conditions couldn't allow an air medical evacuation from Frei Station, the only way to return to Ushuaia was to sail back through the Drake Passage. Because of rough seas, the captain decided against an emergency crossing to Ushuaia, but the ship was able to leave Antarctica for Ushuaia in the evening of November $25^{\text {th }}$.

\section{DISCUSSION}

Nowadays, a study carried out on a similar explorer ships, found a passengers median age of 68 years old and cardiovascular diseases represented up to $6 \%$ of the pathologies encountered on board [4]. Regarding cardiovascular disease, a study aboard 5 large cruise ships requiring telemedical cardiology consultation, with 100 patients, found that almost a fifth of them had a history of coronary heart disease. This study showed that the most common symptom was chest pain (50\%). An abnormal electrocardiogram was present in $92 \%$ of the cases and the most common diagnosis was acute coronary syndrome, followed by atrial arrhythmias [5]. In emergency departments ashore, it was reported that acute coronary syndrome is the most common cause of sudden death $[6,7]$.

The occurrence of coronary heart disease appears to be closely related to weather conditions. Exposure to cold is a triggering factor in myocardial infarction and the risk is higher in the elderly and patients with a coronary history [8-12]. Heavy snowfall and strong wind increase the risk of coronary events among the elderly $[13,14]$. Exposure to a $1^{\circ} \mathrm{C}$ decrease in the daily mean temperature increases by $2 \%$ the risk of myocardial infarction for 28 days, with a more pronounced risk between 2 and 14 days post-exposure [15]. Hard climatic conditions - freezing cold, strong wind, heavy snowfall - prevail in Antarctica [2], and may have a drastic impact on passengers when hiking ashore or during a zodiac cruise.

Mechanisms leading to influence of cold on the onset of acute coronary events are known. Cold stimulates skin receptors and sympathetic nervous activity which leads to a rise in catecholamine levels and a peripheral vasoconstriction. It increases blood pressure, heart rate, cardiac work and myocardial oxygen requirements and reduces the ischaemic threshold. A drop in temperature increases diuresis with an increase in blood viscosity and haemoconcentration. Cold causes an increase in coagulation factors as fibrinogen and platelets counts which may promote acute thrombosis $[8,10,16-19]$.

Considering the remoteness and the extreme weather conditions of the Antarctic Peninsula and its surroundings, the area presents a high risk for navigation as well as for medical care. Medical evacuations are hazardous and mostly not available $[2,20]$. The combination of temperatures below $0^{\circ} \mathrm{C}$, strong winds with heavy gusts and snowfall compromises medical aircraft rescue [2]. Indeed, in the Antarctic Peninsula, the only way for a medical evacuation by air is from Frei Station located on King George Island (South Shetland Island - 62 ${ }^{\circ} 12^{\prime} 0^{\prime \prime}$ South; 58 $57^{\prime} 51^{\prime \prime}$ West) where the availability of the only aircraft runway depends on freezing, wind and visibility conditions [20]. In case of the unavailability of this runway, 2 days at sea crossing the Drake Passage, often on rough seas, are compulsory to reach Ushuaia. This isolation, although often forgotten on board, is strongly felt in these critical situations.

Before an Antarctic cruise, passengers with history of heart diseases should be aware of the increased cardiovascular risks because of the weather conditions. They must know that medical evacuations may be hard and delayed because of the area remoteness combining to its hard weather.

\section{REFERENCES}

1. International Association of Antarctica Tour Operators. Tourism Statistics http://iaato org/tourism-statistics 30; 04: 2018.

2. Mills $\mathrm{CN}$, Mills $\mathrm{GH}$, Mills $\mathrm{GH}$, et al. Challenges of air medical evacuation from Antarctica. Air Med J. 2008; 27(6): 281-285, doi: 10.1016/j.amj.2008.07.009, indexed in Pubmed: 18992687.

3. Analitis A, Katsouyanni K, Biggeri A, et al. Effects of cold weather on mortality: results from 15 European cities within the PHEWE project. Am J Epidemiol. 2008; 168(12): 1397-1408, doi: 10.1093/aje/ kwn266, indexed in Pubmed: 18952849.

4. Carron M, Emeyriat N, Levraut J, et al. Cruise ship pathologies in remote regions. Int Marit Health. 2018; 69(2): 75-83, doi: 10.5603/ IMH.2018.0012, indexed in Pubmed: 29939383.

5. Novaro GM, Bush HS, Fromkin KR, et al. Cardiovascular emergencies in cruise ship passengers. Am J Cardiol. 2010; 105(2): 153-157, doi: 10.1016/j.amjcard.2009.09.004, indexed in Pubmed: 20102910.

6. Bjørnsen LP, Naess-Pleym LE, Dale J, et al. Description of chest pain patients in a Norwegian emergency department. Scand Cardiovasc J. 2019; 53(1): 28-34, doi: 10.1080/14017431.2019.1583362, indexed in Pubmed: 30760035.

7. Goodacre S, Cross E, Arnold J, et al. The health care burden of acute chest pain. Heart. 2005; 91(2): 229-230, doi: 10.1136/ hrt.2003.027599, indexed in Pubmed: 15657244.

8. Caussin C, Escolano S, Mustafic H, et al. CARDIO-ARSIF Registry Investigators. Short-term exposure to environmental parameters and onset of ST elevation myocardial infarction. The CARDIO-ARSIF registry. Int J Cardiol. 2015; 183: 17-23, doi: 10.1016/j. ijcard.2015.01.078, indexed in Pubmed: 25662048. 
9. Barnett AG, Dobson AJ, McElduff P, et al. WHO MONICA Project. Cold periods and coronary events: an analysis of populations worldwide. J Epidemiol Community Health. 2005; 59(7): 551-557, doi: 10.1136/jech.2004.028514, indexed in Pubmed: 15965137.

10. Abrignani MG, Corrao S, Biondo GB, et al. Influence of climatic variables on acute myocardial infarction hospital admissions. Int J Cardiol. 2009; 137(2): 123-129, doi: 10.1016/j.ijcard.2008.06.036, indexed in Pubmed: 18694607.

11. Lin S, Soim A, Gleason KA, et al. Association Between Low Temperature During Winter Season and Hospitalizations for Ischemic Heart Diseases in New York State. J Environ Health. 2016; 78(6): 66-74, indexed in Pubmed: 26867294.

12. Madrigano J, Mittleman MA, Baccarelli A. and al. Temperature, myocardial infarction, and Mortality: effect modification by individual- and area-level characteristics. Epidemiology. 2013; 24(3): 439-46.

13. Hopstock LA, Fors AS, Bønaa KH, et al. The effect of daily weather conditions on myocardial infarction incidence in a subarctic population: the Tromsø Study 1974-2004. J Epidemiol Community Health. 2012; 66(9): 815-820, doi: 10.1136/jech.2010.131458, indexed in Pubmed: 21652517.

14. Goerre S, Egli C, Gerber S, et al. Impact of weather and climate on the incidence of acute coronary syndromes. Int J Cardiol. 2007;
118(1): 36-40, doi: 10.1016/j.ijcard.2006.06.015, indexed in Pubmed: 16904213.

15. Bhaskaran K, Hajat S, Haines A, et al. Short term effects of temperature on risk of myocardial infarction in England and Wales: time series regression analysis of the Myocardial Ischaemia National Audit Project (MINAP) registry. BMJ. 2010; 341: c3823, doi: 10.1136/ bmj.c3823, indexed in Pubmed: 20699305.

16. Wilmshurst P. Temperature and cardiovascular mortality. BMJ. 1994; 309(6961): 1029-1030, doi: 10.1136/bmj.309.6961.1029, indexed in Pubmed: 7950726.

17. Claeys MJ, Rajagopalan S, Nawrot TS, etal. Climate and environmental triggers of acute myocardial infarction. Eur Heart J. 2017; 38(13): 955-960, doi: 10.1093/eurheartj/ehw151, indexed in Pubmed: 27106953.

18. Manou-Stathopoulou V, Goodwin CD, Patterson T, et al. The effects of cold and exercise on the cardiovascular system. Heart. 2015; 101(10): 808-820, doi: 10.1136/heartjnl-2014-306276, indexed in Pubmed: 25673528.

19. Kloner R. Natural and Unnatural Triggers of Myocardial Infarction. Progress in Cardiovascular Diseases. 2006; 48(4): 285-300, doi: 10.1016/j.pcad.2005.07.001.

20. Carron M, Globokar P, Sicard BA. Acute gastrointestinal haemorrhage on board a cruise ship in the Antarctic Peninsula. Int Marit Health. 2016; 67(4): 223-226, doi: 10.5603/IMH.2016.0040, indexed in Pubmed: 28009388. 